\title{
Tanggulangi Stunting: Edukasi Kesehatan pada Ibu Hamil, Ibu Menyusui dan Ibu Balita di Nagari Parit, Pasaman Barat
}

\author{
Welly Femelia dan Idral Purnakarya \\ Fakultas Kesehatan Masyarakat, Universitas Andalas, Kampus Limau Manis, Padang, 25163. Indonesia \\ E-mail: wellyfemelia@ph.unand.ac.id
}

Keywords:

education, mother stunting, toddler

Kata Kunci: balita, edukasi, ibu, stunting

\begin{abstract}
Nutritional problems occur in almost all age groups including children. Pasaman Barat district is one of the stunting focus locations in West Sumatra with an incidence rate of 32.09\% Therefore this community service held in Pasaman Barat District. This health promotion activity aimed to increase mother's knowledge and skill to overcome stunting incident on children. Method used in this activity is counseling and demonstration. Health promotion was attended by 45 women of childbearing age consisting of 15 pregnant women, nursing mothers and toddler mothers each. Counseling held separately for each group meanwhile in the demonstration session all of participants were joining together to compete on making the nutritious supplementary food. This activity succeeded in having a positive impact on the target group. This can be seen from the enthusiasm of the target in participating at each stage of the activity and in discussion session. The activity was closed by making a commitment to follow up the activity together with the district health office, Parit Primary Health Care and Parit Village party.
\end{abstract}

\begin{abstract}
ABSTRAK
Masalah gizi terjadi hampir pada semua kelompok usia termasuk anak - anak. Kabupaten Pasaman Barat merupakan salah satu lokasi fokus stunting yang ada di Provinsi Sumatera Barat dengan angka kejadian mencapai 32,09\%. Oleh karena itu, kegiatan pengabdian ini memilih lokasi di Kabupaten Pasaman Barat, tepatnya Nagari Parit. Kegiatan edukasi kesehatan ini bertujuan untuk meningkatkan pengetahuan dan keterampilan ibu dalam penanggulangan kejadian stunting pada balita. Metode yang digunakan adalah penyuluhan dan demonstrasi/praktek. Edukasi kesehatan ini diikuti oleh 45 orang wanita usia subur yang terdiri dari masing - masing 15 orang ibu hamil, ibu menyusui dan ibu balita. Penyuluhan dilakukan secara terpisah bagi setiap kelompok sasaran sedangkan pada saat demonstrasi ketiga kelompok sasaran digabung untuk berlomba dalam membuat makanan pendamping ASI yang bergizi. Kegiatan ini berhasil berdampak positif bagi kelompok sasaran. Hal ini terlihat dari antusiasme sasaran dalam berpartisipasi di setiap tahap kegiatan dan keaktifan dalam sesi diskusi. Kegiatan ditutup dengan pembuatan komitmen tindak lanjut kegiatan bersama unsur Dinas Kesehatan, Puskesmas dan Nagari.
\end{abstract}




\section{PENDAHULUAN}

Jutaan orang di dunia mengalami masalah gizi dalam berbagai bentuk (Branca, 2019). Pada balita masalah gizi bisa berbentuk kurus, pendek dan kegemukan/obesitas. Hampir separuh kematian yang terjadi pada balita disebabkan oleh kurang gizi (under nutrition). Kurang gizi dan penyakit infeksi memiliki pola interaksi timbal balik sehingga membuat kondisi penderitanya menjadi lebih buruk (UNICEF, 2019). Jika tidak ditanggulangi masalah kurang gizi pada balita dapat mengarah kepada masalah kesehatan lintas generasi (WHO, 2012).

Stunting merupakan keadaan tubuh yang pendek dan sangat pendek hingga melampaui defisit -2 SD dibawah median panjang atau tinggi badan (Manary\&Solomons, 2009). WHO merekomendasikan penggunaan Z-skor untuk menganalisa data antropometri di negara berpendapatan rendah (Gibson, 2005). Seorang anak dianggap pendek jika hasil pengukuran Zskor tinggi badan menurut umur (TB/U) kurang dari -2 SD (Kepmenkes RI, 2010). Stunting memiliki dampak yang besar terhadap penderitanya. Dampak jangka pendek balita stunting adalah terjadinya kesakitan dan kematian, perkembangan kognitif, motorik dan verbal tidak optimal. Dampak jangka panjang yang mungkin dialami adalah postur tubuh tidak optimal, berisiko obesitas, penurunan kesehatan reproduksi, kapasitas belajar dan produktivitas tidak optimal (Kemenkes RI, 2018).

Jumlah balita stunting di seluruh dunia mencapai 140 juta kasus $(21,3 \%)$. Jumlah kasus lebih tinggi dua kali lipat pada masyarakat miskin dibandingkan dengan masyarakat yang tergolong mampu. Sebagian besar kasus stunting tersebut berada di kawasan Benua Asia. Kawasan Asia Tenggara merupakan kawasan benua Asia dengan prevalensi stunting tertinggi kedua setelah Asia Selatan (UNICEF, 2019).

Indonesia termasuk negara dengan prevalensi stunting tinggi $(20-<30 \%)$ (Kemenkes RI, 2018). Pada tahun 2017 Indonesia termasuk negara dengan prevalensi stunting sangat tinggi yaitu 29,6\% (Kemenkes RI, 2018). Angka ini terus mengalami penurunan sehingga pada tahun 2019 prevalensi stunting pada balita di Indonesia adalah 27,67\% (Kemenkes RI, 2019). Walaupun terjadi penurunan yang cukup besar dalam waktu dua tahun tetapi Indonesia masih berada dalam kondisi yang mengkhawatirkan.

Pada tahun 2017, prevalensi stunting di Provinsi Sumatera Barat sedikit lebih tinggi dibandingkan prevalensi nasional yaitu 30,6\%. Kabupaten Pasaman Barat merupakan salah satu dari 19 Kabupaten/Kota yang ada di Provinsi Sumatera Barat. Tingginya angka stunting di kabupaten ini $(32,9 \%)$ menjadikan Pasaman Barat salah satu lokasi fokus (lokus) stunting di Sumatera Barat (TNP2K, 2018).

Metode dalam kesehatan masyarakat terbagi menjadi empat yaitu promosi kesehatan, pencegahan primer, sekunder dan tersier. Promosi kesehatan adalah proses memampukan individu dan masyarakat untuk mengendalikan hal - hal yang mempengaruhi kesehatan mereka demi meningkatkan derajat kesehatan mereka. Upaya promosi kesehatan dapat dilakukan oleh organisasi atau perorangan dengan berbagai latar belakang yang bekerja untuk tujuan yang sama yaitu untuk meningkatkan kesehatan dan kualitas hidup seseorang ataupun masyarakat (Tulchinsky \& Varavikova, 2009).

Promosi kesehatan dapat berbentuk edukasi kesehatan yang bertujuan meningkatkan pengetahuan dan kesadaran sehingga sasaran dapat membuat pilihan yang tepat terkait kehidupan dan kesehatan. Latihan, bermain peran, praktek dan konseling merupakan metode yang banyak digunakan dalam promosi kesehatan (Laverack, 2007). Salah satu penelitian yang 
menunjukkan bahwa edukasi kesehatan berhubungan signifikan dengan peningkatan pengetahuan adalah penelitian yang dilakukan oleh Hati \& Pratiwi tahun 2019. Hasil penelitiannya menunjukkan bahwa edukasi yang diberikan kepada ibu dengan anak stunting memiliki efek positif terhadap perkembangan pertumbuhan anak (Hati \& Pratiwi, 2019).

Konsep promosi kesehatan dan pencegahan penyakit merupakan fondasi dari kesehatan masyarakat (Tulchinsky \& Varavikova, 2009). Banyak upaya promosi kesehatan yang telah dilakukan pemerintah untuk menanggulangi masalah stunting di Indonesia. Ibu hamil dan bersalin, balita, anak usia sekolah, remaja dan dewasa muda menjadi sasaran dalam berbagai program. Salah satu program yang ditujukan pada kelompok dewasa muda adalah meningkatkan penyuluhan untuk PHBS, pola gizi seimbang, tidak merokok/mengonsumsi narkoba (Kemenkes, 2018). Di Kabupaten Pasaman Barat upaya penanggulangan stunting ini diatur dalam Peraturan Bupati tentang Konvergensi Pencegahan dan Penanggulangan Stunting di Nagari (Peraturan Bupati, 2019). Kegiatan pengabdian masyarakat ini merupakan salah satu upaya dalam mendukung program pemerintah pusat dan pemerintah Kabupaten Pasaman Barat.

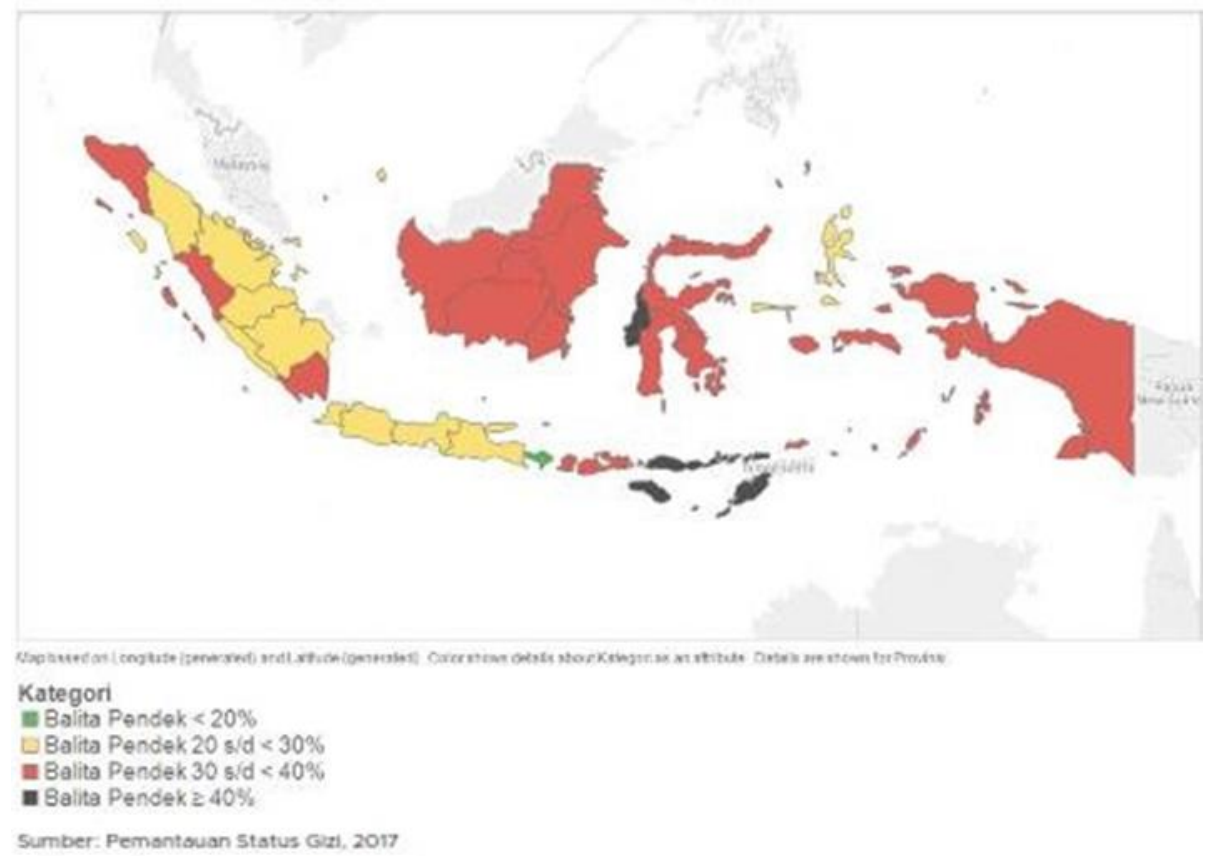

Gambar 1. Peta prevalensi balita pendek di Indonesia tahun 2017.

\section{METODE}

Promosi gizi ini dilakukan di Nagari Parit Kabupaten Pasaman Barat yang merupakan salah satu lokus stunting di Provinsi Sumatera Barat. Terdapat 45 orang ibu yang menjadi sasaran kegiatan yang masing - masing terdiri dari 15 orang ibu hamil, ibu menyusui dan ibu balita. Kegiatan dilakukan dengan menggunakan tiga metode yaitu penyuluhan, demonstrasi dan praktek. Rangkaian kegiatan ini dimulai pada bulan November dan berakhir pada bulan Desember 2019. 
Tahap pertama kegiatan ini adalah pemberian edukasi kesehatan/penyuluhan. Fasilitator pada penyuluhan ini adalah tim dosen dari Universitas Andalas yang terdiri dari dua orang dosen Fakultas Kesehatan Masyarakat. Materi penyuluhan terdiri dari gizi ibu hamil, gizi ibu menyusui dan gizi balita. Untuk lebih kondusif, pada saat penyuluhan kelompok sasaran dibagi menjadi dua kelas dengan durasi penyuluhan lebih kurang 90 menit.

Sesi berikutnya dilakukan demonstrasi "Isi Piringku" yang spesifik ditujukan bagi ibu hamil, ibu menyusui dan balita. Untuk balita disertai dengan cara membuat MPASI (Makanan Pendamping ASI). Pada sesi ini 45 orang ibu dibagi kedalam sembilan kelompok kecil dan masing - masing dipandu oleh seorang fasilitator. Fasilitator pada sesi ini adalah tenaga kesehatan dari Pukesmas Parit Kabupaten Pasaman Barat.

Pertemuan selanjutnya dilakukan praktek penyusunan "Isi Piringku" yang juga dilakukan secara berkelompok. Kegiatan ini dibuat dalam konsep kompetisi sehingga para ibu berusaha maksimal mengaktulisasikan informasi yang telah mereka terima pada sesi sebelumnya. Pemenang dalam lomba ini akan mendapatkan reward yang disediakan oleh pihak Universitas Andalas dan Kantor Wali Nagari Parit.

Bagian akhir dari kegiaatan adalah rapat Rencana Tindak Lanjut (RTL). Rapat ini dipimpin oleh salah satu dosen FKM Unand dan dihadiri oleh tim Puskesmas Nagari Parit, perwakilan Dinas Kesehatan Kabupaten Pasaman Barat, pihak Wali Nagari Parit, kelompok ibu PKK, kader posyandu, dan perwakilan jorong. Dalam rapat ini dihasilkan kesepakatan RTL yang akan dilakukan di masing - masing tingkatan.

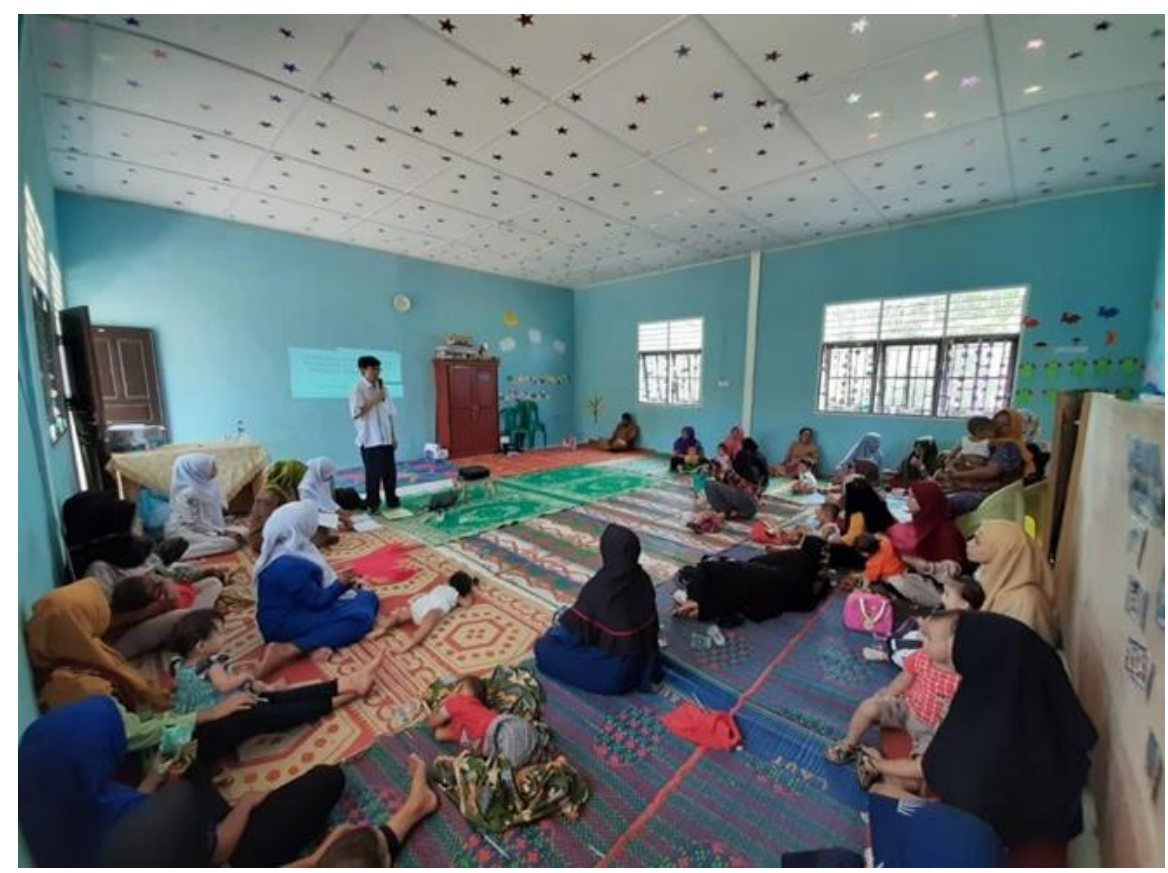

Gambar 2. Pembukaan kegiatan yang dihadiri oleh perwakilan Dinas Kesehatan, Puskesmas Parit, kantor Wali Nagari Parit dan peserta kegiatan. 


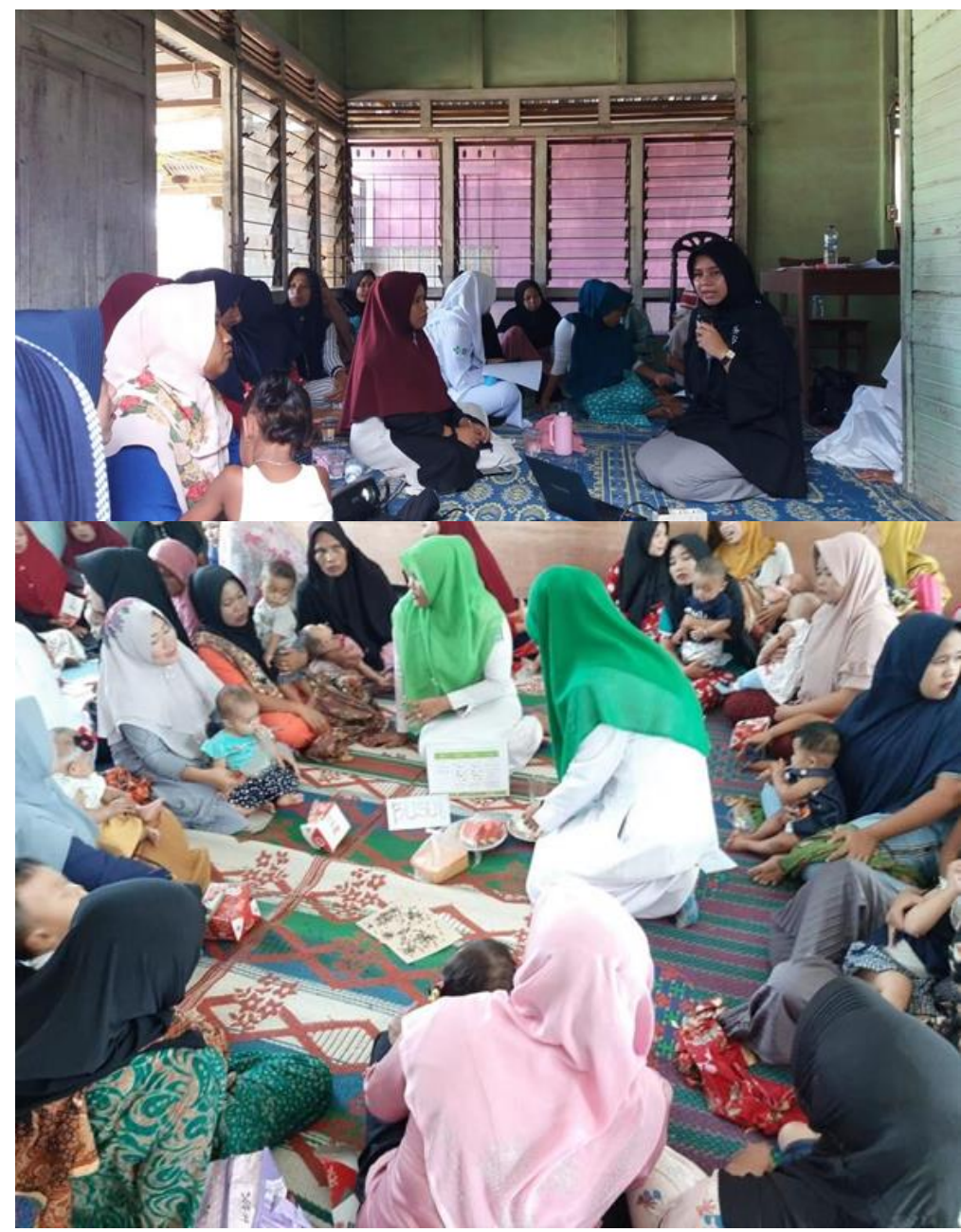

Gambar 3. Kegiatan demonstrasi pembuatan makanan ibu hamil, menyusui, dan balita.

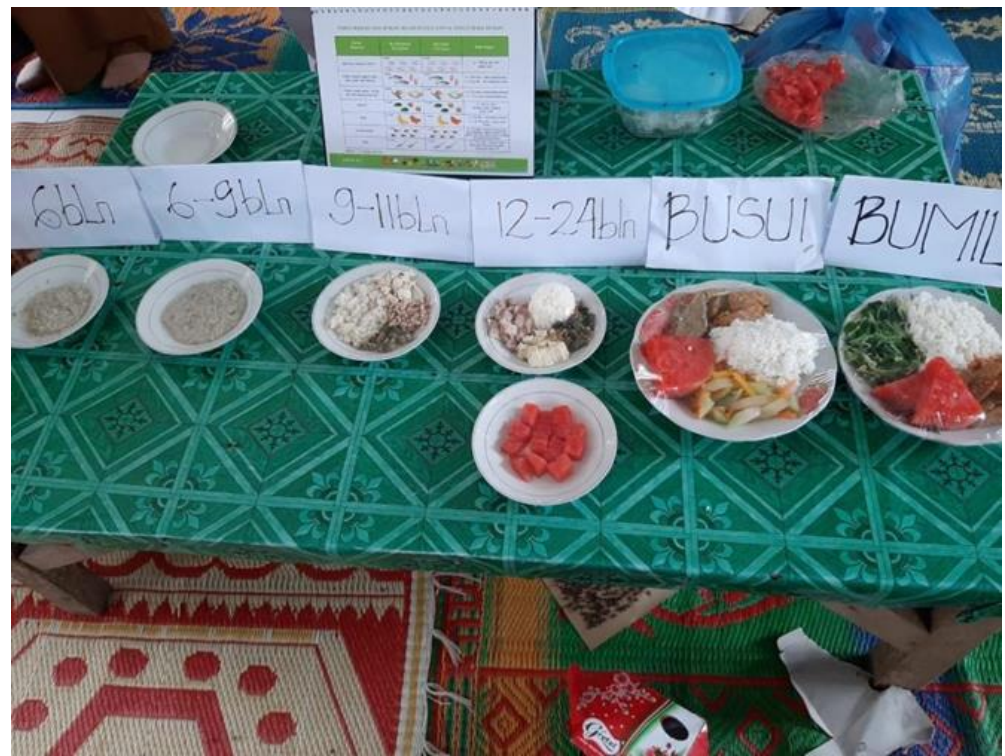

Gambar 4. Hasil praktek pembuatan makanan pendamping ASI oleh kelompok sasaran. 


\section{HASIL DAN PEMBAHASAN}

Di setiap sesi, kegiatan promosi gizi dilakukan pagi hingga siang hari dengan memanfaatkan salah satu bangunan sekolah PAUD sebagai tempat penyelenggaraan. Kegiatan diawali dengan penyuluhan gizi yang bertujuan untuk meningkatkan pengetahuan kelompok sasaran. Materi penyuluhan disampaikan secara bertahap yang terdiri dari materi gizi ibu hamil, ibu menyusui, dan gizi balita. Sebelum penyuluhan diberikan, dibagikan kuesioner kepada setiap responden yang berisi 10 pertanyaan tentang gizi pada masa hamil, masa menyusui dan masa balita. Kuesioner ini menggambarkan pengetahuan awal yang dimiliki oleh kelompok sasaran. Setelah responden selesai mengisi kuesioner, fasilitator menyampaikan materi selama 30 menit kemudian dilanjutkan dengan sesi diskusi selama \pm 60 menit. Setiap sesi penyuluhan dilakukan dengan skema yang sama.

Tahapan berikutnya adalah demonstrasi "Isi Piringku" yang terdiri dari satu porsi makan ibu hamil, ibu menyusui dan porsi makan balita usia $0-6$ bulan, $6-9$ bulan dan $9-12$ bulan. Titik kritis pada bagian ini adalah jenis, jumlah dan bentuk/tekstur makanan yang untuk setiap kelompok sasaran. Sesi ini diawali dengan penjelasan tentang "Isi Piringku" yang disampaikan oleh Tenaga Pelaksana Gizi (TPG) Pukesmas Parit. Kemudian 45 orang ibu dibagi kedalam sembilan kelompok kecil dan dipandu oleh tenaga gizi ataupun tenaga kesehatan lain dari Pukesmas Parit Kabupaten Pasaman Barat dalam demonstrasi dan diskusi tentang penyusunan "Isi Piringku".

Pertemuan selanjutnya dilakukan praktek pembuatan "Isi Piringku" oleh masing - masing kelompok sasaran. Setiap kelompok diberi sejumlah uang (sama untuk masing - masing kelompok) untuk membeli bahan - bahan yang dibutuhkan dalam membuat makanan untuk lomba. Menu masakan yang akan dibuat ditentukan sendiri oleh kelompok. Setelah semua kelompok siap menyusun masakan di dalam piring masing - masing maka juri melakukan penilaian.

Juri dalam kompetisi ini terdiri dari 3 orang yaitu perwakilan dari dosen, TPG puskesmas dan staf dinas kesehatan. Penilaian dilakukan dengan membandingkan aspek ketepatan jumlah, jenis bahan yang digunakan, cita rasa, tekstur makanan dan penampilan. Berdasarkan skor yang diperoleh peserta maka ditetapkan juara satu, dua, tiga dan juara favorit. Setiap pemenang memperoleh hadiah berupa bingkisan dan sejumlah uang yang disediakan oleh FKM Universitas Andalas dan Kantor Wali Nagari Parit.

Berdasarkan kuesioner pre test dan post tes yang dibagikan kepada sasaran maka diperoleh hasil yang memuaskan yaitu terjadi peningkatan pengetahuan setelah dilakukan edukasi. Sebelum edukasi diberikan rentang skor peserta adalah 50 - 80 poin, mengalami peningkatan setelah edukasi yaitu 60 - 100 poin. Kelompok sasaran yang paling baik tingkat pengetahuannya adalah kelompok ibu balita, sebaliknya yang paling rendah pengetahuannya adalah kelompok ibu hamil.

Bentuk RTL yang disepakati dari kegiatan ini adalah:

A. Dinas Kesehatan

1. Pembekalan lanjutan tentang gizi ibu dan anak bagi TPG Puskesmas

2. Pembinaan kerjasama lintas sektor dalam penyelesaian masalah gizi di Kabupaten Pasaman Barat

3. Pemisahan jadwal posyandu ibu dan posyandu balita 
B. Puskesmas

1. Melakukan pelatihan PMBA bagi kader

2. Pengadaan alat ukur di 36 posyandu di Nagari Parit

3. Demosntrasi PMBA pada kegiatan PKK di kecamatan

4. Pemberdayaan kelompok sasaran edukasi sebagai peer - educator bagi ibu - ibu lain yang belum mengikuti kegiatan edukasi dari FKM Unand

C. Kantor Wali Nagari

1. Pelaksanaan edukasi "isi piringku" bagi masyarakat nagari

2. Dukungan dana bagi dinas kesehatan dan puskesmas dalam penanggulangan stunting

D. Kader

1. Melakukan edukasi gizi di posyandu secara berkala menggunakan metode emo - demo

2. Menjadi peer - educator bagi para ibu dalam kegiatan edukasi

\section{KESIMPULAN}

Kegiatan edukasi kesehatan untuk penanggulangan stunting di Nagari Parit Kabupaten Pasaman Barat dapat dikatakan berhasil. Hal ini terlihat dari adanya peningkatan pengetahuan ibu setelah dilakukan penyuluhan tentang gizi ibu hamil, gizi ibu menyusui dan gizi balita. Kemampuan ibu dalam mempersiapkan makanan sesuai dengan kondisi fisiologisnya juga meningkat melalui kegiatan demonstrasi dan praktek penyusunan "Isi Piringku". Secara kuantitatif, selama dua bulan pelaksanaan kegiatan jumlah peserta tidak mengalami penurunan. Diharapkan pengetahuan dan keterampilan yang telah ditransfer kepada sasaran dapat diaktulisasikan dalam kehidupan sehari - hari sehingga kasus balita stunting di Kabupaten Pasaman Barat mengalami penurunan.

\section{UCAPAN TERIMA KASIH}

Ucapan terima kasih disampaikan kepada Kementerian Kesehatan RI yang telah memberikan bantuan pendanaan melalui hibah kerjasama dengan Fakultas Kesehatan Masyarakat Universitas Andalas. Selain itu juga atas dukungan nyata dari jajaran Pemerintah Kabupaten Pasaman Barat, Puskesmas Parit, dan Wali Nagari Parit sehingga kegiatan dapat berjalan lancar.

\section{DAFTAR PUSTAKA}

Branca, F. (2019). https://www.who.int/. Dipetik April 2020, dari WHO: https://www.who.int/nutrition/topics/world-food-day-2019-malnutrition-world-healthcrisis/en/ 
Gibson, RS. (2005). Principles of Nutiritional Assessment. Oxford University Press: New York Hati, F. S., \& Pratiwi, A. M. (2019). The Effect of Education Giving on the Parents Behavior About Growth Stimulation in Children With Stunting. NurseLine Journal, Vol 4 No 1.

Kemenkes RI. (2019). https://www.litbang.kemkes.go.id/. Dipetik April 2020, dari https://www.kemkes.go.id/: https://www.litbang.kemkes.go.id/menggembirakan- angkastunting-turun-31-dalam-setahun/

Kemenkes, R. (2018). Situasi Balita Pendek (Stunting) di Indonesia. Jendela Data dan Informasi Kesehatan.

Kepmenkes RI. (2010). Keputusan Meneteri Kesehatan Nomor 1995 tahun 2010 tentang Standar Antropometri Penilaian Status Gizi anak. Jakarta.

Laverack, G. (2007). Health Promotion Practice. New York: Open University Press.

Manary, MJ \& Solomons NW. (2009). Gizi Kesehatan Masyarakat, Gizi dan Perkembangan Anak. EGC: Jakarta.

Peraturan Bupati. (2019). Peraturan Bupati Pasaman Barat Nomor 34 tahun 2019 tentang Konvergensi Pencegahan dan Penanggulangan Stunting di Nagari. Dipetik April 2020, dari http://dpmn.pasamanbaratkab.go.id/:

http://dpmn.pasamanbaratkab.go.id/pdf/Perbup\%2034\%20Konvergensi\%20Stunting\% 20di\%20Nagari.pdf

TNP2K. (2018). http://tnp2k.go.id/filemanager/. Dipetik April 2020, dari http://tnp2k.go.id/: http://tnp2k.go.id/filemanager/files/Rakornis\%202018/Sesi\%204_01_03\%20\%20Bupati\%20Pasaman\%20Barat\%20pada\%20Rakor\%20Stunting\%202123\%20Nov\%202018.pdf

Tulchinsky, T. A., \& Varavikova, E. A. (2009). The New Public Health (Second Edition). San Diego: Academic Press.

UNICEF. (2019). https://data.unicef.org/. Dipetik April 2020, dari https://unicef.org/: https://data.unicef.org/topic/nutrition/malnutrition/

WHO. (2012). Knowledge Summary: Women's\&Children's Health, 18\# Nutrition. Geneva. 